\title{
Calculating component temperatures in gearboxes for transient operation conditions
}

\author{
Constantin Paschold ${ }^{1}$ (D) $\cdot$ Martin Sedlmair $^{1}$ (D) $\cdot$ Thomas Lohner $^{1}$ (D) $\cdot$ Karsten Stahl $^{1}$
}

Received: 11 April 2021 / Accepted: 30 July 2021 / Published online: 13 September 2021

(c) The Author(s) 2021

\begin{abstract}
The knowledge of component temperatures during transient operation conditions is essential for an optimal design of a gearbox. This is because critical peak temperatures limit the transferable power as well as the load capacity. Moreover, understanding the thermal behavior of the gearbox is key to improving its efficiency. Therefore, the Thermal Network Method (TNM) of the calculation program WTplus was extended to calculate component temperatures in gearboxes for transient operation conditions. Specifically, the TNM considers the component masses and specific heat capacities of each node modelling the gearbox structure. This enables the algorithm to compute a corresponding system of differential equations and thus determine the temperature change over time. Therefore, WTplus can be used to identify critical gearbox component temperatures during load cycles. The applied method was validated with measurements collected at the FZG gear efficiency test rig.
\end{abstract}

\section{Berechnung der Komponententemperaturen in Getrieben unter instationären Betriebsbedingungen}

\section{Zusammenfassung}

Bei der Getriebeauslegung ist die Kenntnis der Komponententemperaturen unter instationären Betriebsbedingungen entscheidend, da kritische Temperaturspitzen die maximal übertragbare Leistung und die Tragfähigkeit beschränken. Darüber hinaus ist das Verständnis des Wärmehaushalts ein Schlüssel zur Steigerung des Getriebewirkungsgrads. Hierzu wurde die in das Berechnungsprogramm WTplus implementierte Methode thermischer Netzwerke weiterentwickelt, um Komponententemperaturen unter instationären Betriebsbedingungen berechnen zu können. Die Getriebestruktur wird dabei durch Knotenpunkte unter Berücksichtigung individueller Komponentenmassen und spezifischer Wärmekapazitäten modelliert. Durch Lösen des entstehenden Differentialgleichungssystems, kann die zeitliche Temperaturveränderung bestimmt werden. WTplus kann folglich zur Vorhersage auftretender kritischer Komponententemperaturen in Getrieben während Lastzyklen eingesetzt werden. Die angewendete Methode wurde durch Messungen am FZG-Wirkungsgradprüfstand validiert.

Nomenclature

$a[\mathrm{~mm}] \quad$ Centre distance

$b[\mathrm{~mm}] \quad$ Tooth width

$c[J /(\mathrm{kg} \cdot \mathrm{K})] \quad$ Specific heat capacity

$C[J / K] \quad$ Heat capacity

$d[\mathrm{~mm}] \quad$ Diameter

$F_{b t}[N] \quad$ Circumferential force at base circle

Constantin Paschold

paschold@fzg.mw.tum.de

1 Gear Research Centre (FZG), Technical University of Munich (TUM), Boltzmannstraße 15, 85748 Garching near Munich, Germany

$\begin{array}{ll}f_{N}[\mathrm{~N} / \mathrm{mm}] & \text { Line load } \\ H_{V}[-] & \text { Gear power loss factor } \\ H_{V L}[-] & \text { Local gear power loss factor } \\ I[\mathrm{~A}] & \text { Electric current } \\ L[\mathrm{~W} / \mathrm{K}] & \text { Thermal conductance } \\ m[\mathrm{~kg}] & \text { Mass } \\ m_{n}[\mathrm{~mm}] & \text { Normal module } \\ n\left[\mathrm{~min}^{-1}\right] & \text { Rotational speed } \\ p_{e t}[\mathrm{~mm}] & \text { Transverse base pitch } \\ p_{H}\left[\mathrm{~N} / \mathrm{mm}^{2}\right] & \text { Hertzian pressure } \\ P_{a}[\mathrm{~W}] & \text { Power output } \\ P_{A}[\mathrm{~W}] & \text { Power input } \\ P_{V}[\mathrm{~W}] & \text { Power loss } \\ \dot{Q}_{A b}[\mathrm{~W}] & \text { Heat output }\end{array}$




$\begin{array}{ll}R_{e l}[\Omega] & \text { Electric resistance } \\ R_{t h}[\mathrm{~K} / \mathrm{W}] & \text { Thermal resistance } \\ R a[\mu \mathrm{m}] & \text { Arithmetic mean roughness } \\ t[\mathrm{~s}] & \text { Time } \\ T[\mathrm{Nm}] \mid[\mathrm{K}] & \text { Torque I Temperature } \\ u[-] & \text { Gear ratio } \\ U[\mathrm{~V}] & \text { Electric voltage } \\ v_{g}[\mathrm{~m} / \mathrm{s}] & \text { Sliding velocity } \\ v_{t}[\mathrm{~m} / \mathrm{s}] & \text { Circumferential speed } \\ v_{t b}[\mathrm{~m} / \mathrm{s}] & \text { Circumferential velocity at base circle } \\ v_{\Sigma}[\mathrm{m} / \mathrm{s}] & \text { Sum velocity } \\ V\left[\mathrm{~m}^{3}\right] & \text { Volume } \\ x_{1,2}[-] & \text { Addendum modification coefficient } \\ X_{L}[-] & \text { Lubricant factor } \\ z[-] & \text { Number of teeth } \\ \alpha[-] & \text { Regression coefficient acc. to Doleschel [6] } \\ \alpha_{n}\left[{ }^{\circ}\right] & \text { Normal pressure angle } \\ \beta\left[{ }^{\circ}\right] \mid[-] & \text { Helix angle I regression coefficient acc. to } \\ & \text { Doleschel [6] } \\ \gamma[-] & \text { Regression coefficient acc. to Doleschel [6] } \\ \varepsilon[-] & \text { Contact ratio } \\ \varepsilon_{\alpha}[-] & \text { Transverse contact ratio } \\ \eta[\%] & \text { Efficiency } \\ \eta_{\text {oil }}[\mathrm{kg} /(\mathrm{m} \cdot \mathrm{s})] & \text { Dynamic viscosity } \\ \mu[-] & \text { Coefficient of friction } \\ \mu_{m z}[-] & \text { Mean coefficient of friction } \\ v\left[\mathrm{~mm} \mathrm{~m}^{2} / \mathrm{s}\right] & \text { Kinematic viscosity } \\ \varrho\left[\mathrm{kg} / \mathrm{m}^{3}\right] & \text { Density } \\ \varrho_{\text {red }}[\mathrm{m}] & \text { Radius of relative curvature } \\ \xi[-] & \text { Load sharing factor acc. to Doleschel [6] } \\ & \end{array}$

Indices

$0 \quad$ No-load I Environment

1 Pinion

2 Wheel

C Pitch point

D Seal

$f \quad$ Fluid

$i, j \quad$ Number of node

$L \quad$ Bearing

$P \quad$ Load-dependent

$s \quad$ Solid

sh Shaft

$v \quad$ Number of time interval

Z Gearing

\section{Introduction}

The efficiency of a gearbox is strongly affected by its lubricant and component temperatures such as for the gears or bearings. Therefore, the knowledge of the operation temperature is key for an improved gearbox design. During the design phase, the oil temperature is usually considered as a representative temperature of a gearbox. Geiger [14] shows, that a distinct difference in temperature occurs between the individual gearbox components during operation. Consequently, the gearbox design can be improved by considering the individual component temperatures rather than a "global" gearbox temperature.

The calculation program WTplus [41] has been developed to investigate the efficiency and heat balance of gearbox systems. The efficiency calculation is based on the power loss of gears, bearings, seals and other rotating elements. The subsequent calculation of the gearbox's heat balance is based on the "Thermal Network Method" (TNM) [14], which is a mathematical method for determining the heat transfer between individual components, as well as the heat dissipation to the environment. It uses the analogy between electric current and heat flow by using Ohm's law on equivialent physical values:

$I=\frac{U}{R_{e l}} \quad:=\quad \dot{Q}=\frac{\Delta T}{R_{t h}}$

This allows the use of Kirchhoff's circuit laws on gearbox systems which were suitably abstracted by nodal points, forming the basis for an efficient and accurate calculation of component temperatures.

In this study, the TNM in WTplus as shown by the authors in [32] is extended to calculate gearbox component temperatures for transient operation conditions.

\section{Power loss calculation}

Calculating the heat balance of a gearbox requires a precise knowledge of the gearboxes power losses. An overview on the state of art power loss and efficiency calculation for gearboxes with spur gears is given in the following. The calculation of the efficiency $\eta$ of a gearbox requires the knowledge of either the power input $P_{A}$ and power loss $P_{V}$, or the power input $P_{A}$ and power output $P_{a}$ :

$\eta=\frac{P_{A}-P_{V}}{P_{A}}=\frac{P_{a}}{P_{a}+P_{V}}=\frac{P_{a}}{P_{A}}$

According to ISO/TR14179-2 [15], the overall power loss $P_{V}$ can be described as the sum of partial power losses of the gearbox components as shown in Eq. 3. They are usually caused significantly by the gears $(Z)$ and bearings $(L)$, and by contacting seals $(D)$. Depending on the gearbox, other power losses $(X)$ from auxiliary units, for exam- 
ple, may also occur. Gear and bearing power losses can be subdivided into no-load $(0)$ and load-dependent $(P)$ losses:

$$
\begin{aligned}
P_{V}= & \underbrace{P_{V Z 0}+P_{V Z P}}_{\text {gear power losses }}+\underbrace{P_{V L 0}+P_{V L P}}_{\text {bearing power losses }}+\underbrace{P_{V D}}_{\text {seal powerlosses }} \\
& +\underbrace{P_{V X}}_{\text {other powerlosses }}
\end{aligned}
$$

In terms of the power loss calculation, values for every single one of the named forms of power loss are needed in as much detail as possible. Thus, a lot of research focuses on the formulation of calculation models to quantify loaddependent and no-load power losses. Common and recent calculation models for predicting power losses in spur gears are presented below.

\subsection{Load-dependent gear power losses}

Gear power losses generally cause a significant proportion of the overall power loss. Friction within the rolling-sliding contact of tooth flanks results in load-dependent gear power losses $\left(P_{V Z P}\right)$. They can be described as the integral of line load $f_{N}$, coefficient of friction $\mu$ and sliding velocity $v_{g}$ across the area of contact, divided by the transverse base pitch $p_{e t}$ :

$$
\begin{aligned}
& P_{V Z P}= \\
& \frac{1}{p_{e t}} \cdot \int_{y=0}^{b} \int_{x=A}^{E} f_{N}(x, y) \cdot \mu(x, y) \cdot v_{g}(x, y) d x d y
\end{aligned}
$$

Assuming a mean gear coefficient of friction $\mu_{m z}$, and extending Eq. 4 by $F_{b t} / F_{b t}$ and $v_{t b} / v_{t b}$, the following can be formulated:

$$
\begin{aligned}
& P_{V Z P}=\underbrace{F_{b t} \cdot v_{t b}}_{P_{A}} \cdot \mu_{m z} \\
& \cdot \underbrace{\frac{1}{p_{e t}} \cdot \int_{y=0}^{b} \int_{x=A}^{E} \frac{f_{N}(x, y)}{F_{b t}} \cdot \frac{v_{g}(x, y)}{v_{t b}} d x d y}_{H_{V(L)}}
\end{aligned}
$$

Based on the introduction of the gear loss factor $H_{V}$ or $H_{V L}$, the equation to calculate the load-dependent gear power losses $P_{V Z P}$ reduces to:

$$
P_{V Z P}=P_{A} \cdot \mu_{m z} \cdot H_{V(L)}
$$

The mean gear coefficient of friction $\mu_{m z}$ represents the "tribological" share of the load-dependent gear power loss. In terms of spur gears, there are several empirical approaches and calculation models available, e.g. Stribeck [42], Michaelis [26], Fernandes et al. [9] or Jurkschat et al. [16]. A widely used and easily applicable model was derived by Schlenk [36], who describes the mean gear coefficient of friction $\mu_{m z}$ as:

$\mu_{m z}=0.048 \cdot\left(\frac{\frac{F_{b t}}{b}}{v_{\Sigma \mathrm{C}} \cdot \rho_{\mathrm{redC}}}\right)^{0.2} \cdot \eta_{\mathrm{oil}}{ }^{-0.05} \cdot R a^{0.25} \cdot X_{L}$

Doleschel [7] derived a more comprehensive model based on the load sharing concept for mixed lubrication. The mean gear coefficient of friction $\mu_{m z}$ is then calculated by a mean solid coefficient of friction $\mu_{m z, s}$ and mean fluid coefficient of friction $\mu_{m z}$, multiplied by their load share described by the fluid load portion $\xi$ :

$\mu_{m z}=(1-\xi) \cdot \mu_{m z, s}+\xi \cdot \mu_{m z, f}$

The mean solid coefficient of friction $\mu_{m z, s}$ and mean fluid coefficient of friction $\mu_{m z, f}$ are calculated by empirical equations:

$$
\begin{aligned}
\mu_{m z, s}= & \mu_{m z, s \mid \mathrm{ref}} \cdot\left(\frac{p_{H, C}}{p_{\mathrm{ref}}}\right)^{\alpha_{s}} \cdot\left(\frac{v_{\Sigma, C}}{v_{s \mid \mathrm{ref}}}\right)^{\beta_{s}} \\
\mu_{m z, f}= & \mu_{m z, f \mid \mathrm{ref}} \cdot\left(\frac{p_{H, C}}{p_{\mathrm{ref}}}\right)^{\alpha_{f}} \cdot\left(\frac{v_{\Sigma, C}}{v_{f \mid \mathrm{ref}}}\right)^{\beta_{f}} \\
& \cdot\left(\frac{\eta_{\mathrm{oil}}}{\eta_{\mathrm{ref}}}\right)^{\gamma_{f}}
\end{aligned}
$$

The reference values for the mean solid and fluid coefficient of friction $\mu_{m z, s \mid \text { ref }}$ and $\mu_{m z, f \mid \text { ref }}$ as well as the regression coefficients $\alpha_{s, f}, \beta_{s, f}$ and $\gamma_{f}$ are tribosystem-specific based on efficiency testing according to FVA345 [6].

The gear loss factor $H_{V}$ was originally derived by Ohlendorf [29]. It represents the "geometrical" share of the loaddependent gear power losses as it only depends on the tooth normal force and sliding speed within the area of contact. Considering a nominal gear geometry and simplified load distribution, $H_{V}$ reads:

$$
\begin{gathered}
H_{V}=\frac{\pi \cdot(u+1)}{z_{1} \cdot u \cdot \cos \left(\beta_{b}\right)} \cdot\left(1-\varepsilon_{\alpha}+\varepsilon_{1}^{2}+\varepsilon_{2}^{2}\right) \\
\text { for } \quad\left\{\begin{array}{l}
1 \leq \begin{array}{l}
\varepsilon_{\alpha} \leq 2 \\
\varepsilon_{1,2} \leq 1
\end{array}
\end{array}\right.
\end{gathered}
$$

Wimmer [46] derived extensions to Eq. 11 to match a broader range of gear types. He also derived a numerically calculated gear loss factor $H_{V L}$, which considers the local load distribution based on a loaded tooth contact analysis. $H_{V L}$ is referred to as local gear loss factor.

\subsection{No-load gear power losses}

Power losses due of the interaction between moving gears and their surrounding fluids are referred to as no-load gear power losses $\left(P_{V Z 0}\right)$ as they are independent from the ap- 
plied load. $P_{V Z 0}$ is typically classified into churning losses, squeezing losses, impulse losses and windage losses. Since the prediction of the interaction between moving gears and their surrounding fluids is highly complex, most calculation models are of empirical nature.

Churning losses often build the main share of no-load losses for dip-lubricated gearboxes. The churning power losses are result of teeth dipping into the oil sump, causing oil displacement. Popular calculation models for spur gears were derived by Mauz [25] and Walter [44]. Squeezing losses can be present for dip- and injection-lubricated gearboxes. Power is used to pump oil into tooth gaps at the gear meshing zone and to squeeze it out again. Thereby, oil is displaced in the rolling and axial direction. Commonly used calculation models for spur gears were also derived by Mauz [25] and Walter [44]. Impulse losses occur due to the impingement of oil injected on gears. The impulse power losses are relevant for injection-lubricated gearboxes and can be calculated by the models of Ariura [1] or Butsch [2]. Windage losses result from the interaction between gears and a secondary fluid (mostly air). Power is used to ventilate the secondary fluid or fluid mixtures in the gearbox housing. The windage power losses are mostly relevant for high rotational speeds and can be calculated by the model of Maurer [24]. Besides empirical equations for noload gear power losses, the computational fluid dynamics (CFD) has proven to have large potential [19-22].

\subsection{Bearing power losses}

Relative movement between the inner and outer bearing ring as well as the cage and rolling elements causes bearing power losses. Schleich [35] refers to rolling friction, sliding friction, inner lubricant friction and ventilation as main causes. Several calculation models exist.

For example, the bearing manufacturers SKF [38] (cf. Eq. 12) and Schaeffler/INA/FAG [34] (cf. Eq. 13) provide empirical calculation models for their specific bearing designs.

$$
\begin{aligned}
& P_{V L, S K F}=\left(T_{r r}+T_{s l}+T_{\text {seal }}+T_{\text {drag }}\right) \cdot 2 \cdot \pi \cdot n \\
& P_{V L, I N A}=\left(T_{V L 0}+T_{V L P}\right) \cdot 2 \cdot \pi \cdot n
\end{aligned}
$$

More comprehensive approaches considering the stiffness and local friction calculation can be found in Wang [45], implemented in the calculation program LAGER2 [18], and Schleich [35]. Since the calculation methods are local in nature, the number of input parameters increase. Powerful commercial programs are e.g. Bearinx by Schaeffler [33] and SimPro by SKF [37].

\subsection{Seal power losses}

Seal power losses can be calculated according to ISO/TR 14179-2 [15], in which losses are dependent on the shaft diameter as well as the shaft rotation speed:

$P_{V D}=7.69 \cdot 10^{-6} \cdot d_{s h}^{2} \cdot n_{s h}$

Equation 14 only covers radial shaft seals. Mechanical seals cannot be calculated, for instance. According to ISO/TR 14179-2 [15], non-contacting seals result in almost no power loss.

\section{Temperature calculation}

The TNM is used for heat balance and temperature calculation of gearboxes. For example, the TNM was applied by Funck [12], Changenet et al. [3] and Liu et al. [23] on spur gears; Monz [27] and Paschold et al. [32] on worm gears; Fossier et al. [11] on hypoid gears; Chen et al. [4], Durand de Gevigney et al. [8] and Xiao et al. [47] on planetary gears and Sucker [43] on crossed helical gears. All these studies refer to steady state operation conditions, where it is:

$P_{V}-\dot{Q}_{A b}=0$

For the calculation of component temperatures for transient operation conditions, Eq. 15 has to be adapted as followed:

$P_{V}-\dot{Q}_{A b}=C \cdot \frac{d T}{d t}=c \cdot m \cdot \frac{d T}{d t}$

Since the balance between heat output $\dot{Q}_{A b}$ and heat capacity $C$ of single components affects the temperature gradient $d T$, the component's mass $m$ and specific heat capacity $c$ must be considered. Thereby, the solution of the thermal network model becomes a differential equation. Kipp [17] provides a solution to this, using the TNM to describe the heat balance of a permanently excited synchronous machine.

Although there are named approaches for the efficiency and heat balance calculation of gearboxes, only few of them uses an automatic approach to build thermal netwerk models. They either model their investigated gearbox as an isothermal system for which no temperature distribution can be calculated, or they build the thermal network model statically and specifically for a gearbox. Based on Geiger [14] and Paschold et al. [32], a method for an automatic efficiency and heat balance calculation for transient operation conditions is shown in the following. 


\subsection{Steady state operation conditions}

In [32], Paschold et al. described an approach of using the TNM to calculate the heat balance of gearboxes using the example of worm gearboxes. The shown method is applicable to steady state operation conditions. Basically, the expression for a steady state thermal network with $n$ nodes can be formulated as:

$P_{i}-\sum_{j, j \neq i}^{n}\left(T_{i}-T_{j}\right) \cdot L_{i, j}=0$

For a better representation of Eq. 17, an equivalent circuit of a two-node thermal network model for steady state operation conditions is drawn in Fig. 1. At each node, a power source $P_{i}$ is connected, generating a heat flow to the heat sink. Depending on the thermal conductances $L_{i, j}$ between the nodes and the heat sink, certain temperatures $T_{i}$ will set in, to satisfy the equation. Thereby, the temperature of the heat sink, which is usually the environment, is specified as a boundary condition. This gives $n-1$ linearly independent equations, when expressed as matrix, making it suitable for numerical solution:

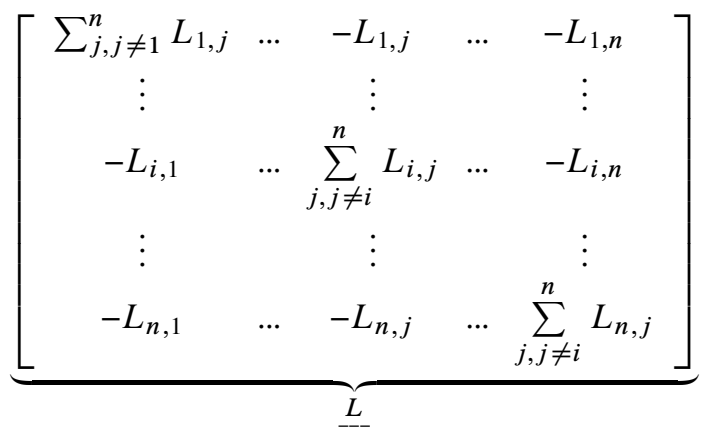

$\cdot \underbrace{\left[\begin{array}{c}T_{1} \\ \vdots \\ T_{i} \\ \vdots \\ T_{n}\end{array}\right]}_{T}=\underbrace{\left[\begin{array}{c}P_{1} \\ \vdots \\ P_{i} \\ \vdots \\ P_{n}\end{array}\right]}_{P}$

$\underline{L}$ is a symmetrical matrix and does only contain values for $L_{i, j}$ where an actual connection between node $i$ and node $j$ exists. Equation 18 can be solved for $T$ by inverting $\underline{L}$ :

$\underline{L} \cdot T=P \Rightarrow T=\underline{L}^{-1} \cdot P$

The inversed matrix $\underline{L}^{-1}$ can be solved by the GaussJordan procedure or the Cholesky procedure for instance. Multiplying by $P$, the temperatures of the single nodes are solved.

\subsection{Transient operation conditions}

To calculate transient operation conditions, more variables must be considered. As shown in Eq. 16, the TNM shown in section 3.1 has to be extended by the variables time $t$ and heat capacity $C$. Extending Eq. 17 represents the full expression for a thermal network model with $n$ nodes:

$P_{i}-\sum_{j, j \neq i}^{n}\left(T_{i}-T_{j}\right) \cdot L_{i, j}=C_{i} \cdot \frac{d T_{i}}{d t}$

Again, for a better representation of Eq. 20, an equivalent circuit of a two-node thermal network for transient operation conditions is drawn in Fig. 2. Compared to Fig. 1, capacitors representing the heat capacity $C_{i}$ are additionally connected to the nodes and the heat sink. This will cause a temperature change over time, depending on the individual heat capacities $C_{i}$. Equation 20 is a differential equation and cannot be solved by the procedure in section 3.1. An analytical solution approach is given by Kipp [17]:

$T(t)=T_{0} \cdot e^{-\frac{t \cdot L_{i}}{C_{i}}}+P_{i} \cdot \frac{1}{L_{i}} \cdot\left(1-e^{-\frac{t \cdot L_{i}}{C_{i}}}\right)$

This solution approach is applicable, when $P_{i}, L_{i}$ and $C_{i}$ are not dependent on time. However, since $P_{i}, L_{i}$ and $C_{i}$

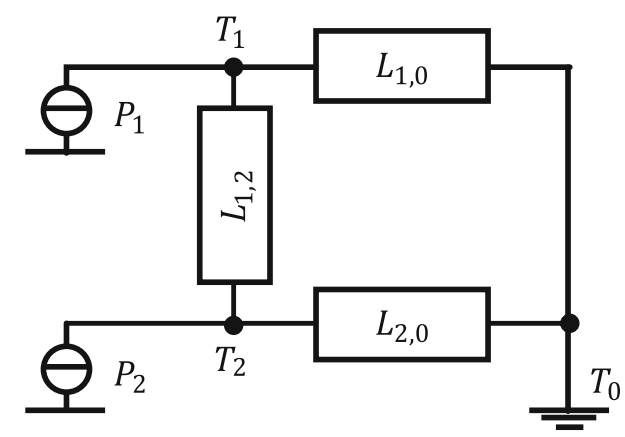

Fig. 1 Equivalent circuit of a two-node thermal network for steady state operation conditions

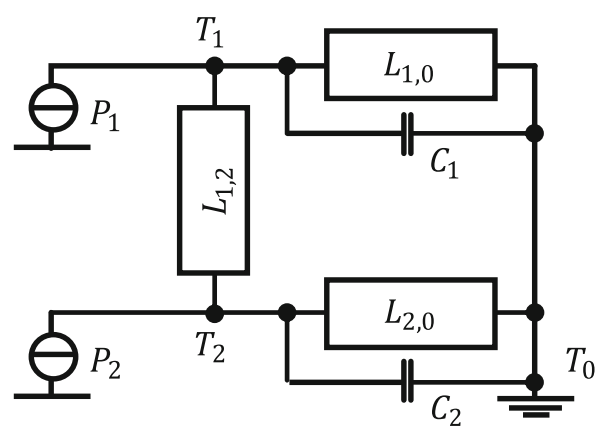

Fig. 2 Equivalent circuit of a two-node thermal network for transient operation conditions following Kipp [17] 
are actually time-dependent, the analytical solution cannot be applied for the total time domain. Therefore, Kipp [17] assumes that for a sufficient short time $\Delta t$, the values for $P_{i}, L_{i}$ and $C_{i}$ can be considered as constant:

$$
P_{i}(t), L_{i}(t), C_{i}(t) \stackrel{\Delta t \rightarrow 0}{\rightarrow} \quad P_{i}, L_{i}, C_{i} \approx \text { constant }
$$

The elapsed time $t_{v}$ up to the time interval $v$ is:

$t_{v}=(v-1) \cdot \Delta t$

with time $\Delta t$ expressed as:

$\Delta t=t_{v+1}-t_{v}$

Substituting $t$ in Eq. 21 by $\Delta t$ from Eq. 24 gives the temperature of a component $i$ for the time interval $v+1$ :

$$
\begin{aligned}
& T\left(t_{v+1}\right)= \\
& T\left(t_{v}\right) \cdot e^{-\frac{\Delta t \cdot L_{i}}{C_{i}}}+P\left(t_{v}\right) \cdot \frac{1}{L_{i}\left(t_{v}\right)} \cdot\left(1-e^{-\frac{\Delta t \cdot L_{i}}{C_{i}}}\right)
\end{aligned}
$$

Finally, extending Eq. 18 by Eq. 25 gives the TNM which can be used to calculate the component temperatures of gearboxes for transient operation conditions.

$\underline{L^{\prime}} \cdot \vec{T}=$

$$
\underbrace{\left[\begin{array}{c}
T_{0,1} \cdot e^{-\frac{\Delta t \cdot L_{1,0}}{C_{1}}}+P_{1} \cdot \frac{1}{L_{1,0}} \cdot\left(1-e^{-\frac{\Delta t \cdot L_{1,0}}{C_{1}}}\right) \\
\vdots \\
T_{0, i} \cdot e^{-\frac{\Delta t \cdot L_{i, 0}}{C_{i}}}+P_{i} \cdot \frac{1}{L_{i, 0}} \cdot\left(1-e^{-\frac{\Delta t \cdot L_{i, 0}}{C_{i}}}\right) \\
\vdots \\
T_{0, n} \cdot e^{-\frac{\Delta t \cdot L_{n, 0}}{C_{n}}}+P_{n} \cdot \frac{1}{L_{n, 0}} \cdot\left(1-e^{-\frac{\Delta t \cdot L_{n, 0}}{C_{n}}}\right)
\end{array}\right]}_{P^{\prime}}
$$

With:

\section{Implementation in calculation program}

WTplus [41] is applicable to gearbox systems containing cylindrical, bevel and hypoid as well as worm and crossed helical gears. So far it has been able to calculate the efficiency and the heat balance only for steady state operation conditions. By implementing routines according to section 3.2, WTplus now becomes able to solve the heat balance for transient operation conditions. A flow chart of the calculation sequence of WTplus is shown in Fig. 3, which will be explained in the following sections.

\subsection{Preprocessing gear data}

First, WTplus reads input data and calculates the macro geometry and parameters. Routines for spur, bevel, hypoid and crossed helical gears according to Niemann et al. [28] and worm gears according to DIN 3975-1 [5] are implemented. If necessary, data is automatically complemented. WTplus then calculates the efficiency and heat balance iteratively (cf. Fig. 3). The calculation of efficiency and heat balance is described in Sect. 4.2 and 4.3.

\subsection{Efficiency calculation}

The calculation program WTplus determines all torques and speeds, including a power flow analysis, according to Stangl [40]. Initially, these torques are not affected by any losses and speeds are only dependent on the kinematics of the gearbox system (E1 in Fig. 3). Next, with the torques and speeds known, forces caused by the gearings are calculated. Subsequently, the gearing forces are put into shaft-bearing context and thus the calculation program determines the reactive bearing forces. Then, the oil data as viscosity and density is calculated at operation condititons to determine the tribological factors (E2 in Fig. 3). Considering these values, the gear, bearing and seal power losses are computed (E3 in Fig. 3, cf. Sect. 2 for spur gears). Finally, the calculation program calculates all torques and speeds

$$
\begin{aligned}
& \underline{L^{\prime}}= \\
& {\left[\begin{array}{ccccc}
1+\left(\frac{\sum_{j, j \neq 1}^{n} L_{1, j}}{L_{1,0}}\right) \cdot\left(1-e^{-\frac{\Delta t \cdot L_{1,0}}{C_{1}}}\right) & \ldots & \left(-\frac{L_{1, j}}{L_{1,0}}\right) \cdot\left(1-e^{-\frac{\Delta t \cdot L_{1,0}}{C_{1}}}\right) & \ldots & \left(-\frac{L_{1, n}}{L_{1,0}}\right) \cdot\left(1-e^{-\frac{\Delta t \cdot L_{1,0}}{C_{1}}}\right) \\
\vdots & \ldots & 1+\left(\frac{\sum_{j, j \neq i}^{n} L_{i, j}}{L_{i, 0}}\right) \cdot\left(1-e^{-\frac{\Delta t \cdot L_{i, 0}}{C_{i}}}\right) & \ldots & \left(-\frac{L_{i, n}}{L_{i, 0}}\right) \cdot\left(1-e^{-\frac{\Delta t \cdot L_{i, 0}}{C_{i}}}\right) \\
\left(-\frac{L_{i, 1}}{L_{i, 0}}\right) \cdot\left(1-e^{-\frac{\Delta t \cdot L_{i, 0}}{C_{i}}}\right) & \ldots & \vdots & \vdots \\
\vdots & \ldots & \left(-\frac{L_{n, j}}{L_{n, 0}}\right) \cdot\left(1-e^{-\frac{\Delta t \cdot L_{n, 0}}{C_{n}}}\right) & \ldots & 1+\left(\frac{\sum_{j, j \neq n}^{n} L_{n, j}}{L_{n, 0}}\right) \cdot\left(1-e^{-\frac{\Delta t \cdot L_{n, 0}}{C_{n}}}\right)
\end{array}\right]}
\end{aligned}
$$


Fig. 3 Flowchart of efficiency and heat balance calculation in WTplus

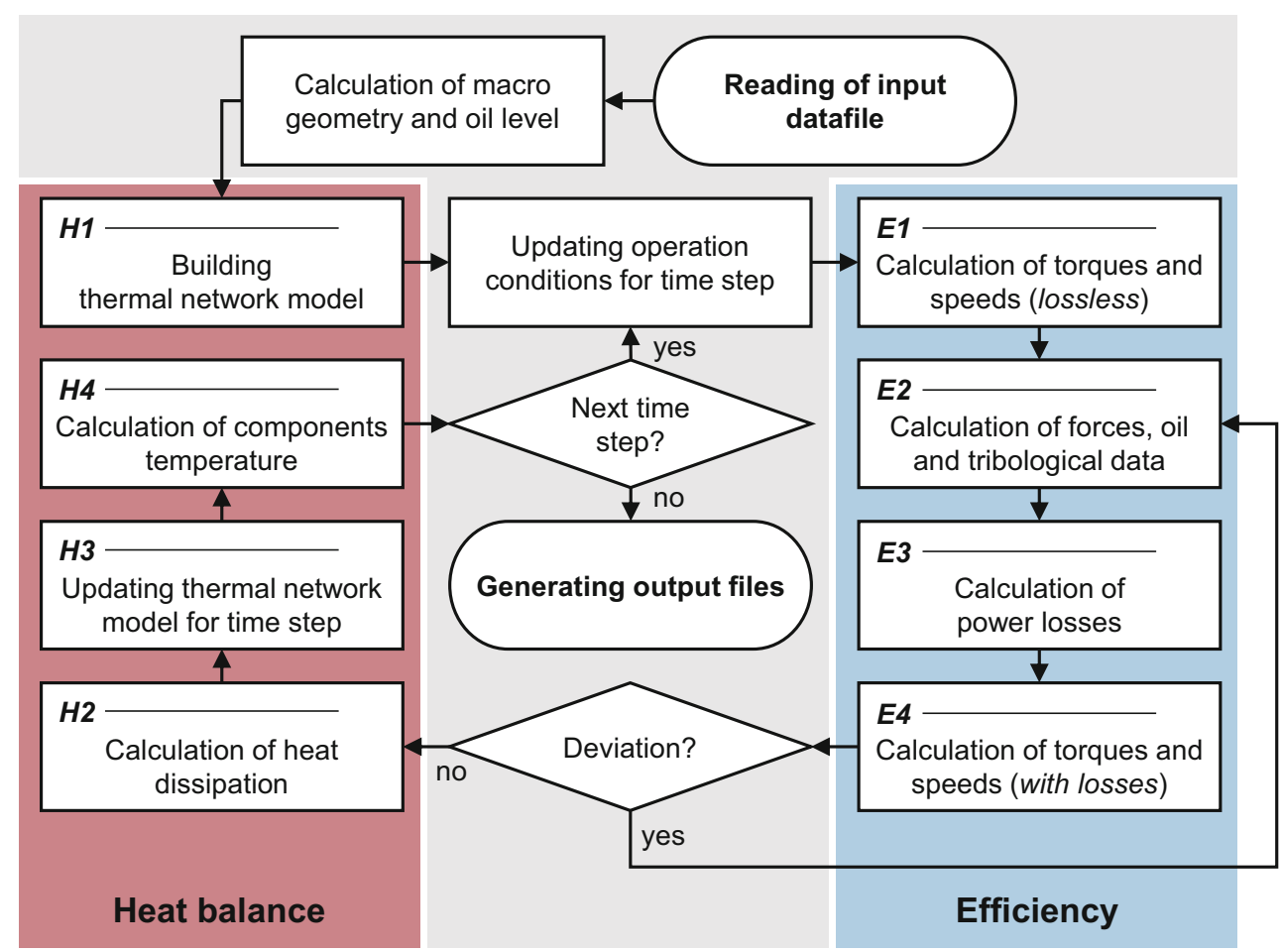

again, but this time considering power losses that reduce the torques (E4 in Fig. 3). Since these reduced torques change the gearing forces, the bearing forces differ and thus power losses change. Therefore, an iterative solution must be considered. If the deviation of the output torques between two subsequent iterations is below a given limit, e.g. $1 \mathrm{~W}$, power losses are considered solved and the heat balance calculation is initiated.

\subsection{Heat balance calculation}

The calculation program WTplus is able to solve local temperatures of single components, based on the TNM explained in Sect. 3. At first a thermal network model is built (H1 in Fig. 3). It is notable that the thermal network is built up fully automatically, modelling the gearbox by suitable nodalization, linking those nodes and calculating necessary thermal conductances. Due to simplicity, the housing is considered as isothermal body, and thus modelled by a single node. This is justified for the FZG test gearbox by thermal imaging camera images taken by Geiger [13]. The housing is linked to the environment, oil sump and bearings. The environment acts as a boundary condition in the form of a heat sink with a specified temperature. The oil sump is assumed to be isothermal and is modelled by a single node, like the housing. Schleich [35] shows that the simplification of bearings as a single node and assuming a mean temperature of the bearing is sufficient. Nodalizing of spur gear stages is done according to Geiger [14]. Fig. 4 shows an example of a nodalized gear shaft with a spur gear. For gear shafts, isothermal sections are generated. The gears are radially subdivided into the gear body, teeth (node not visible) and tooth flanks. Worm gear stages are nodalized according to Paschold et al. [32]. Subsequently, based on calculated power losses, the heat dissipation is calculated either by the equations of Funck [12], who investigated the heat balance of gearboxes to describe the thermal behavior of the gearbox housing or an alteration of his model according to ISO/TR 14179-2 [15] (H2 in Fig. 3). When solving the thermal network model for a new time step, a suitable thermal network for steady state operation conditions according to Geiger [14] and Paschold et al. [32] is built and required temperature conductances are calculated (H3 in Fig. 3). The approach shown in Sect. 3 is applied extending the prior built thermal network by relevant parameters $C_{i}$ and $\Delta t$. The heat capacity $C_{i}$ is automatically calculated for each node by its material and geometrical parameters by:

$C_{i}=c_{i} \cdot m_{i}=c_{i} \cdot \rho_{i} \cdot V_{i}$

According to the calculation model of Funck [12], the foundation is not represented by a specific node. Therefore, the direct consideration of the foundation's heat capacity is not possible. To overcome this shortcoming, the heat capacity of the foundation can be added manually to the housing, since both are directly coupled in the thermal network model (cf. Fig. 5). 


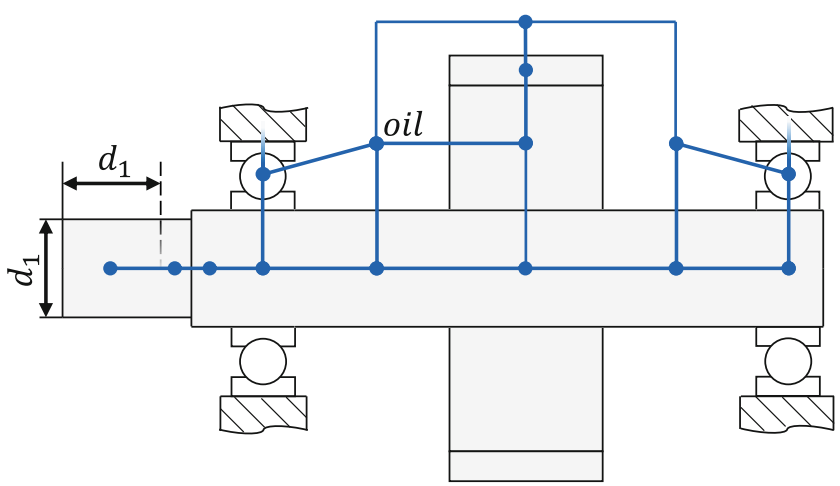

Fig. 4 Example for the distribution of nodes for a gear shaft with spur gear (schematically)

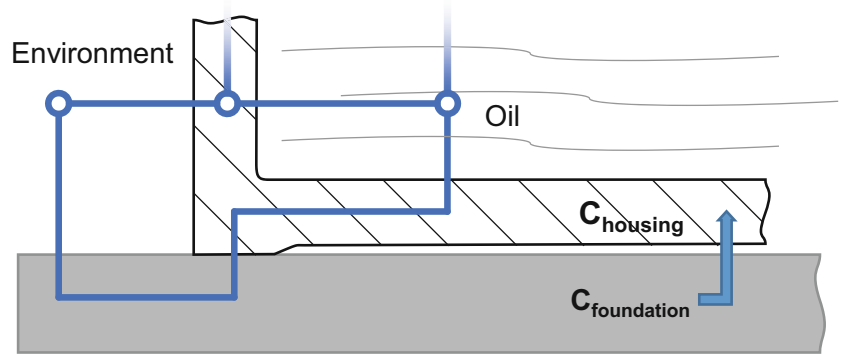

Fig. 5 Consideration of the foundation in the TNM

The thermal network is then solved for the temperatures (H4 in Fig. 3), serving as initial value for the next time step. The size of the time step $\Delta t$ can be specified. This iteration is performed until every time step has been calculated. The accumulated results are finally presented in the output files of WTplus.

\section{Object of investigation and data}

The calculation model as shown in Sect. 4 was validated by numerous measurements of spur gearboxes [13] worm gearboxes [30-32]. In the following, the in this study considered FZG efficiency test rig and particular data is introduced.

\subsection{Object of investigation}

Object of investigation in this study is the test gearbox of the FZG efficiency test rig presented in Fig. 6. Thereby, different gear geometries are considered: a balanced gearing of FZG type-C (C), a low loss gearing (LL) and a deep tooth form gearing (SH). The main geometry data of the considered gearings are given in Table 1.

\subsection{Experimental data}

Experimental data for the object of investigation is taken from Geiger [13], where numerous measurements of transient component temperatures were performed. The gearings were dip-lubricated with an oil level of $-19 \mathrm{~mm}$ relative to the shaft axis (cf. Fig. 6). The main oil data is shown in Table 2. No heating or cooling of the oil was done.

The pinion was rotating counterclockwise when looking at the test gearbox (cf. Fig. 6). For the operation conditions, a no-load condition, a medium load condition and a high load condition is considered. Table 3 summarizes the operation loads and their resulting Hertzian pressure at pitch point.

The kinematic conditions of the experiments are given in Table 4. Beginning with the lowest circumferential speed, the measurement was done consecutively, increasing the speed stepwise after $3 \mathrm{~h}$ of persistence. This was done for each load separately. According to ISO/TR 14179-2 [15]
Fig. 6 Test gearbox of FZG efficiency test rig

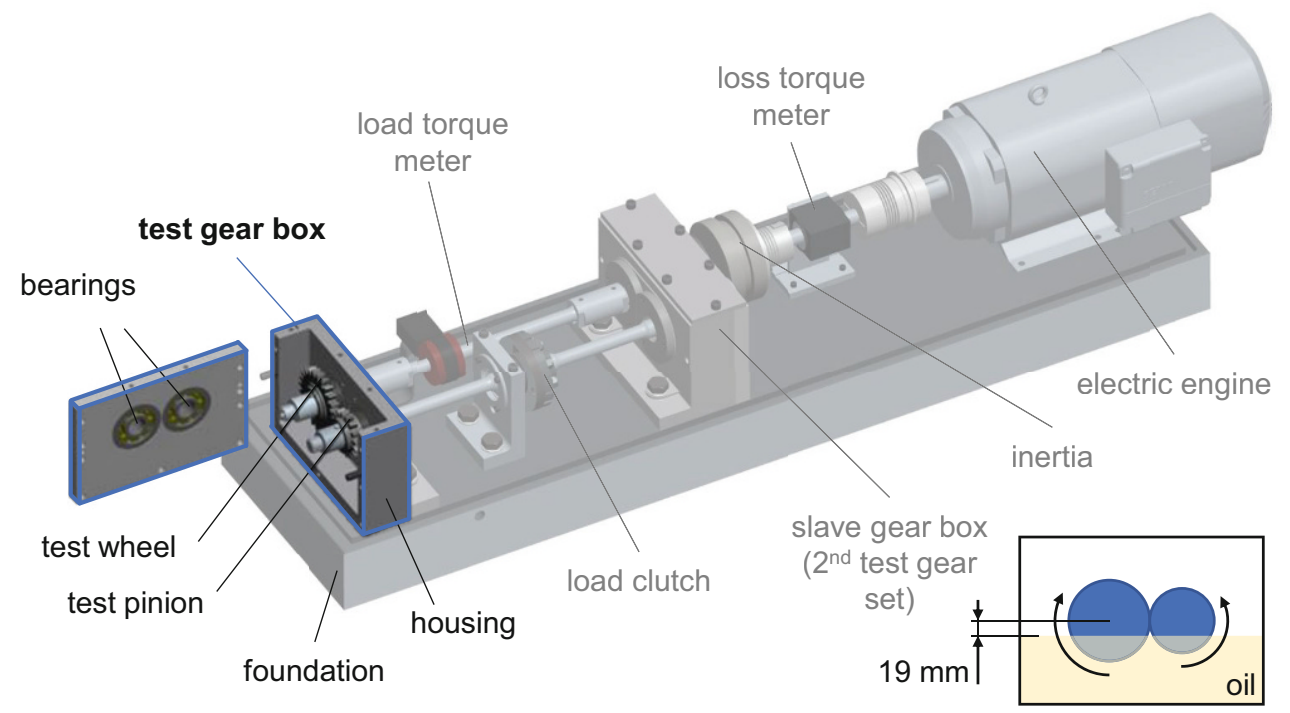


Table 1 Considered gearings and their main geometry data [13]

\begin{tabular}{|c|c|c|c|c|c|c|}
\hline Parameter & Gear & Symbol & Unit & $\mathrm{C}$ & LL & $\mathrm{SH}$ \\
\hline Centre distance & - & $a$ & $\mathrm{~mm}$ & 91.5 & & \\
\hline Number of teeth & Pinion/wheel & $z_{1} / z_{2}$ & - & $16 / 24$ & $35 / 43$ & $29 / 36$ \\
\hline Normal module & Pinion/wheel & $m_{n}$ & $\mathrm{~mm}$ & 4.5 & 2 & 2.44 \\
\hline Normal pressure angle & Pinion/wheel & $\alpha_{n}$ & $\circ$ & 20 & 24.67 & 17.5 \\
\hline Helix angle at pitch circle & Pinion/wheel & $\beta$ & $\circ$ & 0 & 31.0 & 29.5 \\
\hline Face width & Pinion/wheel & $b$ & $\mathrm{~mm}$ & 14 & 25.7 & 17.2 \\
\hline \multirow{2}{*}{$\begin{array}{l}\text { Addendum modification } \\
\text { coefficient }\end{array}$} & Pinion & $x_{1}$ & - & 0.182 & 0.1500 & 0.1523 \\
\hline & Wheel & $x_{2}$ & - & 0.172 & 0.1035 & 0.009 \\
\hline Flank surface roughness & Pinion/wheel & $R a$ & $\mu \mathrm{m}$ & $0.174 / 0.157$ & $0.357 / 0.203$ & $0.152 / 0.150$ \\
\hline Material & Pinion/wheel & - & - & $16 \mathrm{MnCr} 5$ & & \\
\hline
\end{tabular}

Table 2 Main oil data

\begin{tabular}{|c|c|c|c|c|c|}
\hline \multirow[t]{2}{*}{ Name } & \multirow[t]{2}{*}{ Oil type } & \multicolumn{2}{|c|}{ Kin. viscosity $v$ in $\mathrm{mm}^{2} / \mathrm{s}$} & \multirow{2}{*}{$\begin{array}{l}\text { Viscosity } \\
\text { index }\end{array}$} & \multirow[t]{2}{*}{ Density $\rho\left(15^{\circ} \mathrm{C}\right)$ in $\mathrm{kg} / \mathrm{m}^{3}$} \\
\hline & & $\overline{v\left(40^{\circ} \mathrm{C}\right)}$ & $v\left(100^{\circ} \mathrm{C}\right)$ & & \\
\hline FVA2A & Mineral oil & 32.63 & 5.45 & 104 & 876.8 \\
\hline
\end{tabular}

Table 3 Considered operation loads and resulting Hertzian pressures at the pitch point

\begin{tabular}{llllll}
\hline Wheel shaft torque $T_{2}$ & & $\mathrm{Nm}$ & 0 & 141 & 453 \\
\hline Hertzian pressure at pitch point $p_{H, C}$ & $\mathrm{C}$ & $\mathrm{N} / \mathrm{mm}^{2}$ & 0 & 940 & 1660 \\
& $\mathrm{LL}$ & & 0 & 660 & 1150 \\
& $\mathrm{SH}$ & & 0 & 920 & 1590 \\
\hline
\end{tabular}

Table 4 Considered circumferential speeds and resulting wheel shaft speeds

\begin{tabular}{lllllllll}
\hline Circumferential speed at pitch circle $v_{t}$ & $\mathrm{~m} / \mathrm{s}$ & 1 & 2 & 5 & 8.3 & 15 \\
\hline Rotational speed wheel & $\mathrm{C}$ & $\mathrm{min}^{-1}$ & 174 & 348 & 870 & 1444 & 2609 & 3479 \\
shaft $n_{2}$ & $\mathrm{LL}$ & & 189 & 379 & 947 & 1571 & 2840 & 3786 \\
& $\mathrm{SH}$ & & 188 & 377 & 942 & 1564 & 2827 & 3769 \\
\hline
\end{tabular}

Table 5 Considered power loss calculation models

\begin{tabular}{ll}
\hline Load-dependent gear power loss & Doleschel [7], Ohlendorf [29] \\
No-load gear power loss & Mauz [25] \\
Bearing power loss & SKF04 [39] \\
Seal power loss & ISO/TR14179-2 [15] \\
\hline
\end{tabular}

a quasi-stationary temperature in respect of oil temperature is to be expected for dip-lubricated gearboxes after $1-3 \mathrm{~h}$, depending on the gearbox design. For high operation loads and high circumferential speeds, partly no measurements were performed to prevent component temperatures higher than annealing temperatures.

The load is measured with a torque meter on the wheel shaft inside the power circle. The total power loss of the back-to-back configuration is directly measured by a torque meter shaft between the electric motor and the power circle. The gearbox component temperatures were measured by resistance temperature detectors of type Pt100. The sensors were coated by heat-conducting paste and stuck in
Table 6 Regression coefficients for the calculation model of Doleschel [7]

\begin{tabular}{llllllll}
\hline & $\mu_{\text {mz|ref }}$ & $\begin{array}{l}p_{\text {ref }} \text { in } \\
\mathrm{N} / \mathrm{mm}^{2}\end{array}$ & $\begin{array}{l}v_{\text {ref }} \text { in } \\
\mathrm{m} / \mathrm{s}\end{array}$ & $\begin{array}{l}\eta_{\text {ref }} \\
\text { in } \\
\mathrm{mPas}\end{array}$ & $\alpha$ & $\beta$ & $\gamma$ \\
\hline Solid (s) & 0.0863 & 1000 & 0.2 & - & 0.00 & -0.13 & - \\
Fluid (f) & 0.0500 & 1000 & 8.3 & 20 & 0.07 & 0.07 & 0.29 \\
\hline
\end{tabular}

drilled and eroded holes, respectively. They were located at the outer housing side surface below oil level, inner and outer bearing rings and shafts as well as gear bodies and teeth. Additionally, the environmental and the oil sump temperature below oil level were measured. The sensors were connected to a Multifunction I/O Device. Sensor signals of rotating components were transmitted by use of a mercury rotary transmitter.

\subsection{Calculation models and data}

This section describes the considered calculation models and data for the object of investigation. Table 5 shows the 
Table 7 Considered heat balance calculation models and parameters

\begin{tabular}{|c|c|c|}
\hline Time step size & \multicolumn{2}{|l|}{$360 \mathrm{~s}$} \\
\hline $\begin{array}{l}\text { Heat dissipation via the } \\
\text { housing }\end{array}$ & \multicolumn{2}{|c|}{ ISO/TR 14179-2 [ 15] } \\
\hline $\begin{array}{l}\text { Gearbox surface outside } \\
\text { (without bottom) }\end{array}$ & \multicolumn{2}{|l|}{$0.214 m^{2}$} \\
\hline Gearbox surface inside & \multicolumn{2}{|l|}{$0.149 \mathrm{~m}^{2}$} \\
\hline Gearbox height & \multicolumn{2}{|l|}{$0.215 \mathrm{~m}$} \\
\hline Wall thickness & \multicolumn{2}{|l|}{$0.024 \mathrm{~m}$} \\
\hline Emission factor & \multicolumn{2}{|l|}{0.8} \\
\hline $\begin{array}{l}\text { Heat transfer coefficient } \\
\text { between oil and hous- } \\
\text { ing }\end{array}$ & \multicolumn{2}{|l|}{$950 W /\left(m^{2} \cdot K\right)$} \\
\hline $\begin{array}{l}\text { Thermal conductivity of } \\
\text { housing }\end{array}$ & \multicolumn{2}{|l|}{$40 W /(m \cdot K)$} \\
\hline Velocity of cooling air ${ }^{\mathrm{a}}$ & \multicolumn{2}{|l|}{$2 \mathrm{~m} / \mathrm{s}$} \\
\hline $\begin{array}{l}\text { Temperature of cooling } \\
\text { air }^{\mathrm{b}}\end{array}$ & \multicolumn{2}{|l|}{$[25,29]{ }^{\circ} \mathrm{C}$} \\
\hline $\begin{array}{l}\text { Contact surface of forced } \\
\text { cooling air }\end{array}$ & \multicolumn{2}{|l|}{$0.214 \mathrm{~m}^{2}$} \\
\hline $\begin{array}{l}\text { Flow length of cooling } \\
\text { air }{ }^{\mathrm{c}}\end{array}$ & \multicolumn{2}{|l|}{$0.054 m$} \\
\hline $\begin{array}{l}\text { Heat capacity to consider } \\
\text { foundation }^{\mathrm{d}}\end{array}$ & \multicolumn{2}{|l|}{$1336 J /(k g \cdot K)$} \\
\hline $\begin{array}{l}\text { Heat dissipation via the } \\
\text { foundation }\end{array}$ & \multicolumn{2}{|c|}{ ISO/TR 14179-2 [ 15] } \\
\hline Length/Width/Height & \multicolumn{2}{|c|}{$1.200 \mathrm{~m} / 0.420 \mathrm{~m} / 0.030 \mathrm{~m}$} \\
\hline Surface housing bottom & \multicolumn{2}{|l|}{$0.052 \mathrm{~m}^{2}$} \\
\hline Surface housing feet & \multicolumn{2}{|l|}{$0.052 \mathrm{~m}^{2}$} \\
\hline $\begin{array}{l}\text { Heat transfer coeff. be- } \\
\text { tween foundation and } \\
\text { air }\end{array}$ & \multicolumn{2}{|l|}{$40 W /\left(m^{2} \cdot K\right)$} \\
\hline $\begin{array}{l}\text { Thermal conductivity of } \\
\text { foundation }\end{array}$ & \multicolumn{2}{|l|}{$42 W /(m \cdot K)$} \\
\hline $\begin{array}{l}\text { Direction of heat dissipa- } \\
\text { tion }\end{array}$ & \multicolumn{2}{|l|}{ Top } \\
\hline $\begin{array}{l}\text { Heat dissipation via cou- } \\
\text { plings }\end{array}$ & \multicolumn{2}{|c|}{ ISO/TR 14179-2 [ 15] } \\
\hline Shaft & Pinion shaft & Wheel shaft \\
\hline Length of shaft/flange & $0.223 \mathrm{~m} / 0.040 \mathrm{~m}$ & $0.090 \mathrm{~m} / 0.156 \mathrm{~m}$ \\
\hline Diameter of shaft/flange & $0.024 \mathrm{~m} / 0.088 \mathrm{~m}$ & $0.055 \mathrm{~m} / 0.023 \mathrm{~m}$ \\
\hline $\begin{array}{l}\text { Thermal conductivity of } \\
\text { shaft and flange }\end{array}$ & $46 W /(m \cdot K)$ & $46 W /(m \cdot K)$ \\
\hline
\end{tabular}

The investigated gearbox is mounted in a test room for test rigs which is equipped with an air extraction and conditioning system. This leads to a noticeable air flow which is in accordance to Niemann and Winter [28] who state an air flow of over $1.25 \mathrm{~m} / \mathrm{s}$ for machine halls. Since the test room is rather small, a velocity of cooling air of $2 \mathrm{~m} / \mathrm{s}$ is assumed

${ }^{\mathrm{b}}$ According to measurements

${ }^{\mathrm{c}}$ Since there is no unidirectional airflow, an individual contact surface of forced cooling air and contact of flow length of cooling air is assumed

${ }^{\mathrm{d}}$ As per Sect. 4.3, a manual set of the housing's heat capacity is necessary to consider the foundation's heat capacity. Since the foundation is very large compared to the housing, only a share of it will effectively contribute to the transient temperature behavior. Thus, half of its heat capacity is considered used power loss calculation models which were briefly described in section 2 . The regression coefficients for the considered oil (cf. Table 2) based on the calculation model of Doleschel [7] are given in Table 6. Since the determination of the local gear loss factor $H_{V L}$ according to Wimmer [46] would require the use of a loaded tooth contact analysis, the gear loss factor $H_{V}$ according to Ohlendorf [29] is used for simplicity. By coupling WTplus with a loaded tooth contact analysis in RIKOR [10], the local gear power loss factor $H_{V L}$ according to Wimmer [46] can be used in future work.

Heat balance calculations were performed using the TNM described in Sect. 3, considering the nodalization and determination of thermal conductances according to Sect. 4.3. The heat dissipation is calculated by ISO/TR 14179-2 [15] considering the housing, the foundation and couplings. All relevant models and parameters are listed in Table 7.

\section{Results and validation}

The experimental data in section 5.2 is compared to calculation results based on the data shown in section 5.3. Both power losses and transient component temperatures are compared in detail.

\subsection{Power losses}

Fig. 7 shows measured and calculated power losses for the considered test gearbox. The three gearings $\mathrm{C}, \mathrm{LL}$ and $\mathrm{SH}$ are compared for the different operation conditions. The measurements represent a mean value of power losses at the end of each circumferential speed step.

The power loss calculation shows very good agreement with measurement data for all gearing variants and operation conditions. For gearing $\mathrm{C}$, the calculation slightly underestimates the measured power losses, but it shows a close tendency in increasing power losses with increasing circumferential speed. Similar is found for the gearing LL, whereas with increasing circumferential speed, the calculation results show a slightly higher progression. The calculation results for the gearing SH show slightly higher power losses than measured for medium load. For high load, no measurement results are available. It should be noted that the gear loss factor $H_{V}$ acc. to Eq. 11 was used for the calculations considering a nominal gear geometry and simplified load distribution. An even closer match between calculation and measurement may be achieved when using the local gear loss factor $H_{V L}$ considering the local load distribution based on a loaded tooth contact analysis.

Whereas the overall power losses are a measure of the general temperature level, the shares of the partial power 


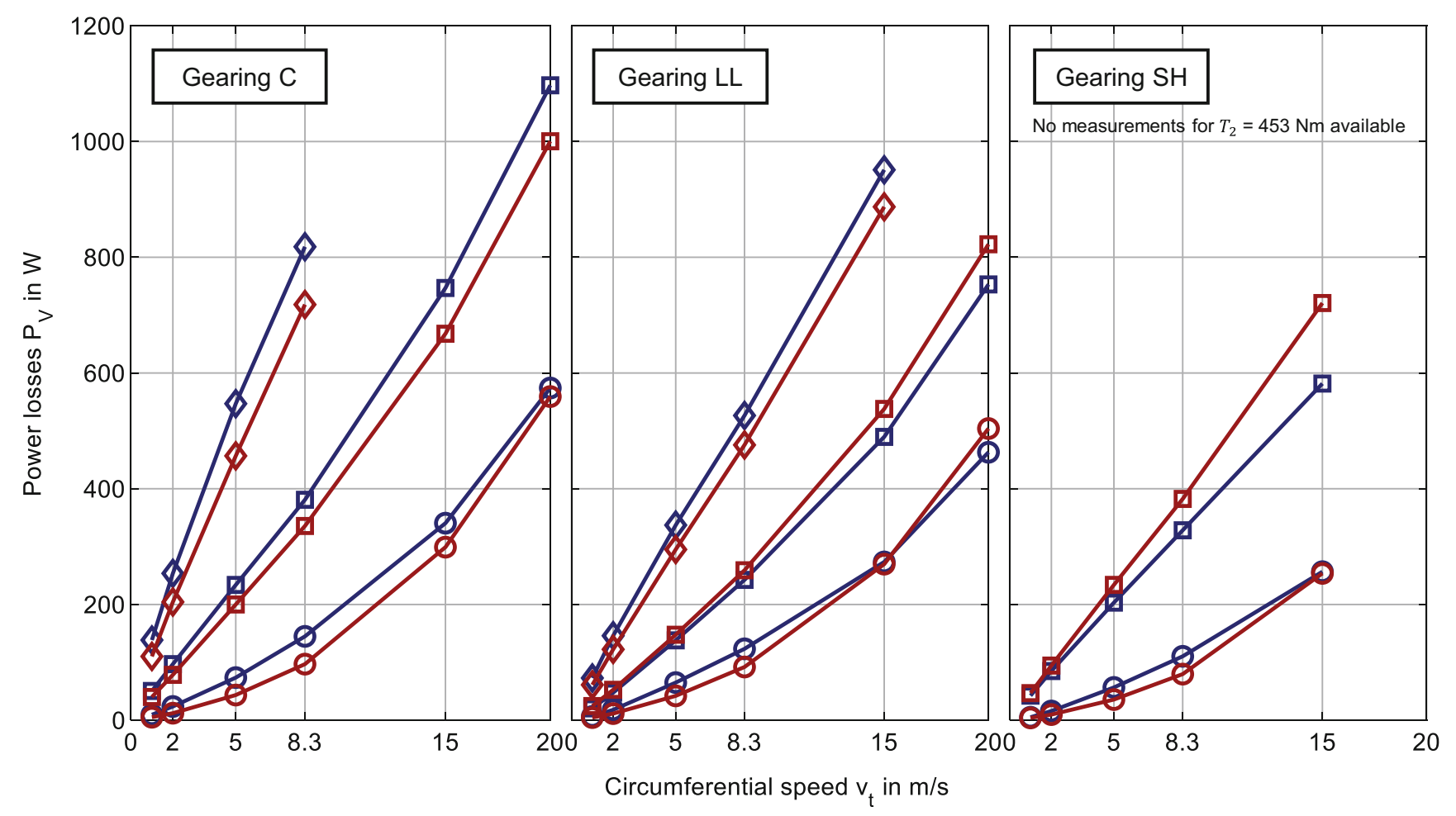

\begin{tabular}{|c|c|c|c|c|}
\hline Measurement & Calculation & $T_{2}=0 \mathrm{Nm}$ & $T_{2}=141 \mathrm{Nm}$ & $\underbrace{T_{2}=453 \mathrm{Nm}}_{2}$ \\
\hline
\end{tabular}

Fig. 7 Comparison of measured and calculated power losses
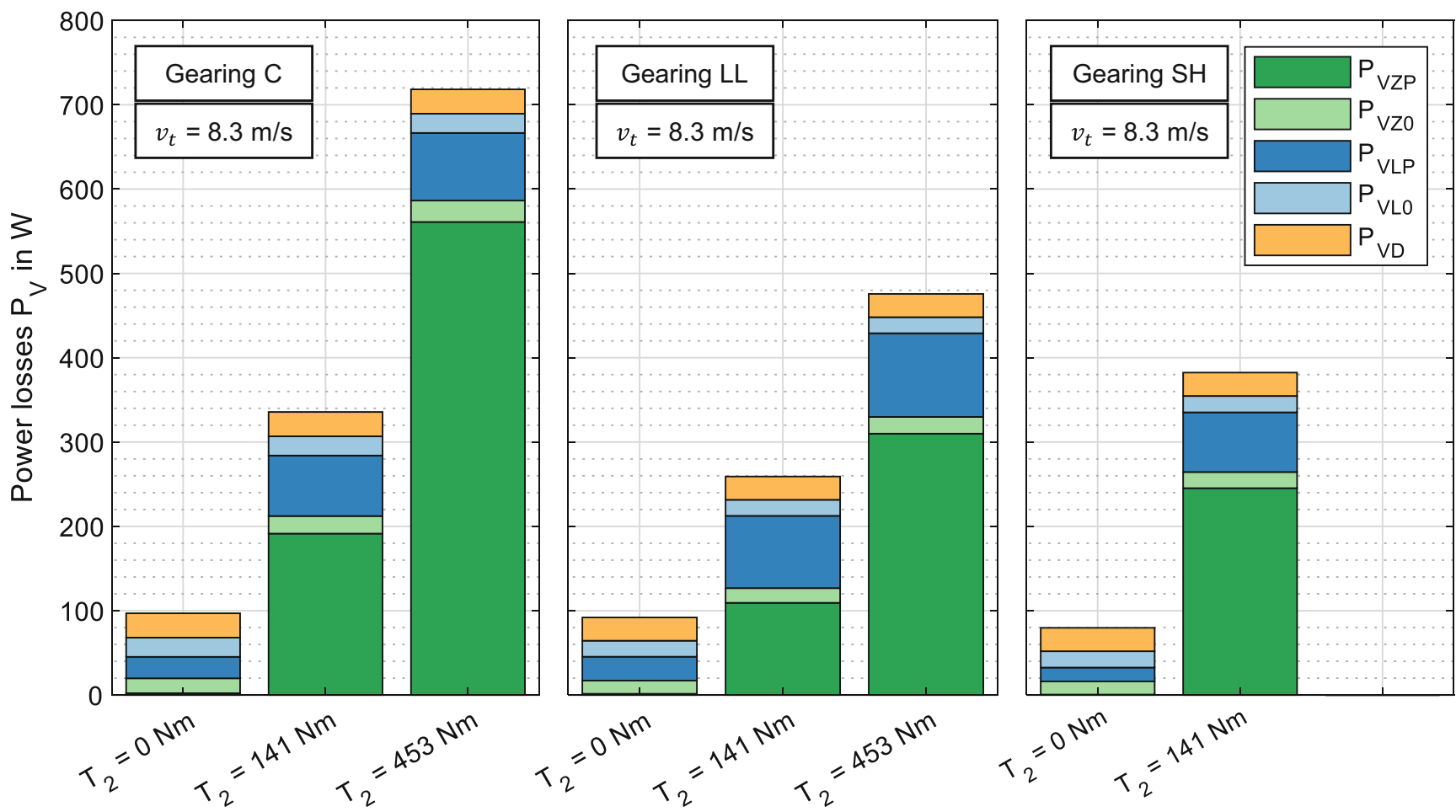

Fig. 8 Comparison of calculated partial power losses for circumferential speed $v_{t}=8.3 \mathrm{~m} / \mathrm{s}$ 

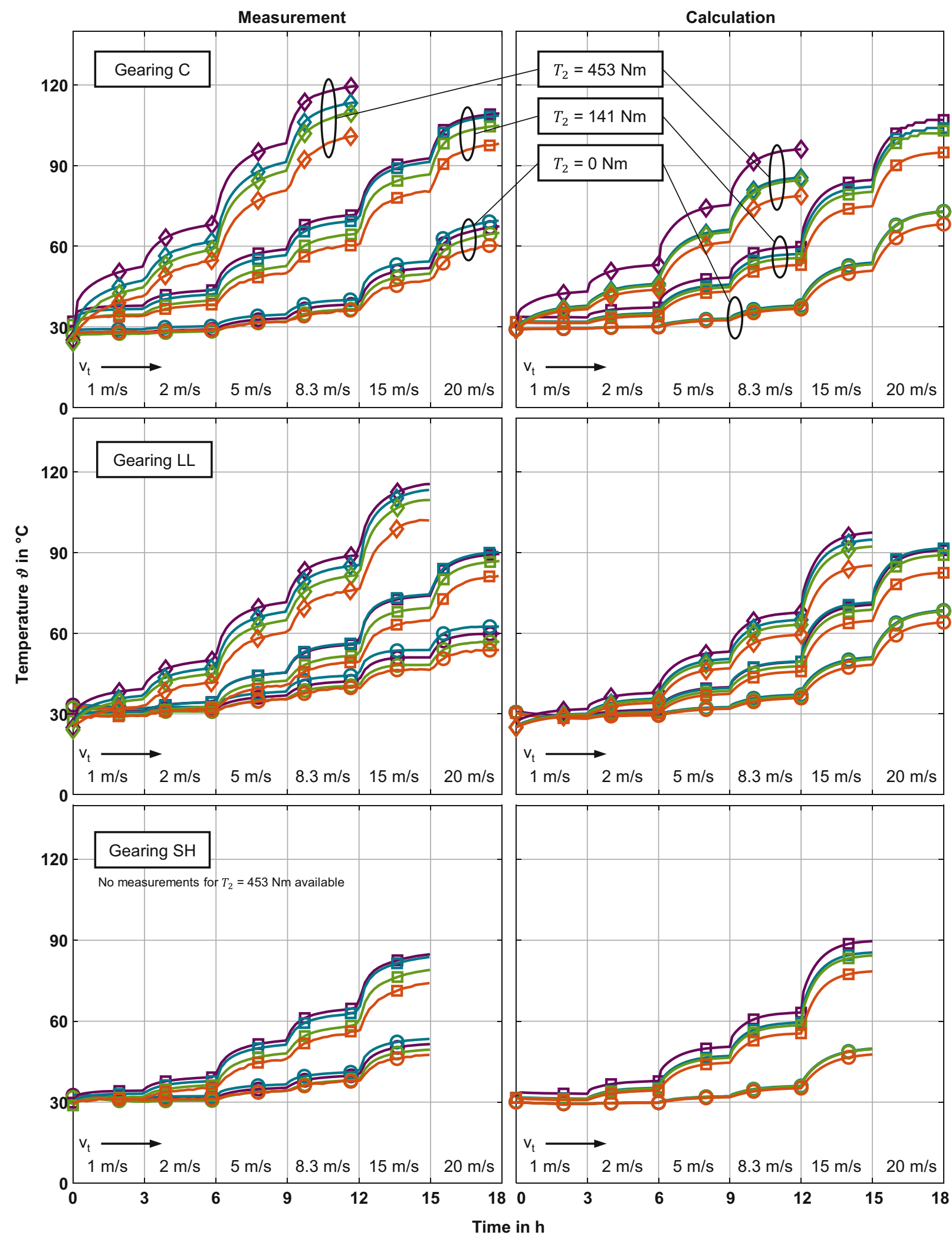

Tooth bulk $\quad$ Bearing $\quad$ Oil $\quad$ Housing $\quad$ T

Fig. 9 Comparison of measured and calculated transient component temperatures 
losses clearly influence the temperature distribution between the different gearbox compontents. Therefore and for a better understanding on how power losses are distributed between the components, Fig. 8 shows calculation results of the partial power losses according to Eq. 3 for all gearing variants and loads exemplarily for the circumferential speed $v_{t}=8.3 \mathrm{~m} / \mathrm{s}$.

It can be seen, that the load-dependent gear and bearing losses increase with higher load. Thereby, the load-dependent gear losses show a pronounced influence. The gearing SH shows the highest load-dependent gear losses followed by gearing $\mathrm{C}$. The gearing LL shows the lowest load-dependent gear losses. Load-dependent bearing losses vary little between the gearing variants. As expected, the no-load gear and bearing power losses as well as the seal power losses are very similar for the variants. The slightly increasing no-load gear losses with higher load are due to the higher operation temperatures resulting in a lower operation oil viscosity. This leads to increased churning losses according to Mauz [25].

\subsection{Component temperatures}

Fig. 9 displays calculated and measured temperatures of the housing, oil, bearing, and tooth bulk for the considered gearing variants. The calculation results for the no-load and medium load operation condition are in very good agreement with the measurements. This can be seen in terms of the temperature level, the temperature gradients, and the temperature distribution between single components. Both the calculation and measurement show the tooth bulk temperature for the gearing $\mathrm{C}$ and $\mathrm{SH}$ as highest and the bearing temperature for the gearing LL as highest. Also, the housing temperature as lowest followed by the oil temperature agrees between measurement and calculation for all gearing variants. All measurement results show a strong transient temperature increase per circumferential speed and even after three hours not a fully steady state condition. This is due to the very large heat capacity of the foundation. The transient temperature trends are reproduced well by the calculation.

For the high load condition, the calculation results underestimate the measurement results. This is result of the calculation model for the heat dissipation which only considers constant geometrical values of the housing and cooling air parameters such as its velocity and temperature (cf. Table 7), calculating a constant heat transfer coefficient for all operation conditions. However, the heat transfer coefficient is expected to be dependent on yet not considered parameters. More refined calculation models for the heat dissipation to the environment are required.

\section{Conclusion}

In this study, an automatic calculation method to determine the component temperatures in gearboxes for transient operation conditions was implemented in the calculation program WTplus. Calculation results of power losses and local temperatures for a spur gearbox with different gearing variants show good agreement with measurements. The temperature distribution between individual components and the temperature gradients are well reproduced. To improve absolute calculation results, refined calculation models for the heat dissipation to the environment are required. These can be experimentally or numerically derived.

Funding The presented results are based on the research project FVA 69 VIII; self-financed by the Research Association for Drive Technology e. V. (FVA). The authors would like to thank for the sponsorship and support received from the FVA and the members of the project committee.

Funding Open Access funding enabled and organized by Projekt DEAL.

Conflict of interest C. Paschold, M. Sedlmair, T. Lohner and K. Stahl declare that they have no competing interests.

Open Access This article is licensed under a Creative Commons Attribution 4.0 International License, which permits use, sharing, adaptation, distribution and reproduction in any medium or format, as long as you give appropriate credit to the original author(s) and the source, provide a link to the Creative Commons licence, and indicate if changes were made. The images or other third party material in this article are included in the article's Creative Commons licence, unless indicated otherwise in a credit line to the material. If material is not included in the article's Creative Commons licence and your intended use is not permitted by statutory regulation or exceeds the permitted use, you will need to obtain permission directly from the copyright holder. To view a copy of this licence, visit http://creativecommons.org/licenses/by/4. $0 /$.

\section{References}

1. Ariura Y, Ueno T, Sunaga T, Sunamoto S (1973) The lubricant churning loss in spur gear systems. Bull JSME 16(95):881-892

2. Butsch M (1989) FVA 44 V - Zahnradschmierung - Turboverluste - Untersuchungen der hydraulischen Leerlaufverluste an schnelllaufenden Stirnradgetrieben mit Umfangsgeschwindigkeit bis $200 \mathrm{~m} / \mathrm{s}$ und Radbreiten bis $125 \mathrm{~mm}$. Abschlussbericht. Forschungsvereinigung Antriebstechnik (FVA) e. V., Frankfurt a.M.

3. Changenet C, Oviedo-Marlot X, Velex P (2006) Power loss predictions in geared transmissions using thermal networks-applications to a six-speed manual gearbox. Tribol Trans 128(3):618

4. Chen LF, Wu XL, Qin DT, Wen ZJ (2011) Thermal network model for temperature prediction in planetary gear trains. Appl Mech Mater 86:415-418

5. DIN 3975-1:2017-09 (2017) Begriffe und Bestimmungsgrößen für Zylinder-Schneckengetriebe mit sich rechtwinklig kreuzenden Achsen - Teil 1: Schnecke und Schneckenrad

6. Doleschel A (2002) FVA 345 Wirkungsgradtest - Vergleichende Beurteilung des Einflusses von Schmierstoffen auf den Wirkungsgrad bei Zahnradgetrieben. Abschlussbericht. FVA, Frankfurt a.M. 
7. Doleschel A (2003) Wirkungsgradberechnung von Zahnradgetrieben in Abhängigkeit vom Schmierstoff. Dissertation, TU München, Garching

8. Durand de Gevigney J, Changenet C, Ville F, Velex P, Becquerelle S (2014) Analysis of no-load dependent power losses in a planetary gear train by using thermal network method. In: International Gear Conference 2014. 26th-28th August 2014, Lyon

9. Fernandes CM, Martins RC, Seabra JH (2016) Coefficient of friction equation for gears based on a modified Hersey parameter. Tribol Int 101:204-217

10. Fingerle A (2020) FVA 592 III - Validierung RIKOR - Validierung der Verformungsrechnung in RIKOR - Detaillierte Betrachtung gekoppelter Getriebesysteme. Abschlussbericht. Forschungsvereinigung Antriebstechnik (FVA) e. V., Frankfurt a.M.

11. Fossier C, Barday D, Changenet C, Ville F, Berier V (2018) Investigations on drive axle thermal behaviour: power loss and heattransfer estimations. SAE Int J Eng 11(1):55-66

12. Funck $G$ (1985) Wärmeabführung bei Getrieben unter quasistationären Betriebsbedingungen. Dissertation, TU München, München

13. Geiger J (2013) FVA 584 I - Instationäre Getriebetemperatur Berechnung der Getriebetemperatur für instationäre Zustände. Abschlussbericht. FVA, Frankfurt a.M.

14. Geiger J (2015) Wirkungsgrad und Wärmehaushalt von Zahnradgetrieben bei instationären Betriebszuständen. Dissertation, TU München, Garching

15. ISO/TR 14179-2:2001-08 (2001) Zahnradgetriebe - Wärmehaushalt

16. Jurkschat T, Lohner T, Stahl K (2019) Improved calculation of loaddependent gear losses by consideration of so far disregarded influences. Proc Inst Mech Eng Part J J Eng Tribol 233(4):509-519

17. Kipp B (2008) Analytische Berechnung thermischer Vorgänge in permanentmagneterregten Synchronmaschinen. Dissertation, Helmut-Schmidt-Universität, Hamburg

18. Leonhardt C, Otto M, Stahl K (2016) FVA 364 V - LebensdauerIndustriegetriebe-Wälzlager - Erweiterung von LAGER2 zur Dimensionierung von Wälzlagern in Industriegetrieben: Mechanische Kontaktgrößen und Tragfähigkeitskennwerte. Abschlussbericht. FVA, Frankfurt a.M

19. Liu H, Jurkschat T, Lohner T, Stahl K (2018) Detailed investigations on the oil flow in dip-lubricated gearboxes by the finite volume CFD method. Lubricants 6:47

20. Liu H, Jurkschat T, Lohner T, Stahl K (2017) Determination of oil distribution and churning power loss of gearboxes by finite volume CFD method. Tribol Int 109:346-354

21. Liu H, Link F, Lohner T, Stahl K (2019) Computational fluid dynamics simulation of geared transmissions with injection lubrication. Proc Inst Mech Eng Part C J Mech Eng Sci 233(21-22): 7412-7422

22. Liu H, Standl P, Sedlmair M, Lohner T, Stahl K (2018) Efficient CFD simulation model for a planetary gearbox. Forsch Ingenieurwes 82(4):319-330

23. Liu Y, Peng J, Wang B, Qin D, Ye M (2018) Bulk temperature prediction of a two-speed automatic transmission for electric vehicles using thermal network method and experimental validation. Proc Inst Mech Eng Part D J Automob Eng 101(3):2585-2598

24. Maurer J (1994) FVA 44 VI - Ventilationsverluste - Leerlaufverluste schnelllaufender Stirnradgetriebe. Abschlussbericht. Forschungsvereinigung Antriebstechnik (FVA) e. V., Frankfurt a.M.

25. Mauz W (1987) Hydraulische Verluste von Stirnradgetrieben bei Umfangsgeschwindigkeiten bis $60 \mathrm{~m} / \mathrm{s}$. Dissertation, Universität Stuttgart

26. Michaelis K (1987) Die Integraltemperatur zur Beurteilung der Fresstragfähigkeit von Stirnradgetrieben. Dissertation, TU München, Garching

27. Monz A (2012) Tragfähigkeit und Wirkungsgrad von Schneckengetrieben bei Schmierung mit konsistenten Getriebefetten. Dissertation, TU München, Garching
28. Niemann G, Winter H (2003) Getriebe allgemein, Zahnradgetriebe - Grundlagen, Stirnradgetriebe, 2nd edn. vol 2. Springer, Berlin, Heidelberg, New York

29. Ohlendorf H (1958) Verlustleistung und Erwärmung von Stirnrädern. Dissertation, TH München, München

30. Paschold C (2018) FVA 69 VII - WTplus - Thermische Betrachtung von Schneckengetrieben in WTplus. Abschlussbericht. FVA, Frankfurt a.M.

31. Paschold C (2020) FVA 69 VIII WTplus - Instationäre Komponententemperaturen - Erweiterung von WTplus um eine Berechnungsmethode zur Bestimmung der lokalen Komponententemperaturen unter instationären Betriebsbedingungen. Abschlussbericht. FVA, Frankfurt a.M.

32. Paschold C, Sedlmair M, Lohner T, Stahl K (2020) Efficiency and heat balance calculation of worm gears. Forsch Ingenieurwes 84(2): $115-125$

33. Schaeffler Technologies AG \& Co. KG BEARINX-online Wellenberechnung. https://www.schaeffler.de/content.schaeffler.de/de/ produkte-und-loesungen/industrie/berechnung-und-beratung/ berechnung/bearinx_online_shaft_calculation/index.jsp. Accessed 9 May 2019

34. Schaeffler Technologies AG \& Co. KG (2015) Wälzlagerpraxis Handbuch zur Gestaltung und Berechnung von Wälzlagerungen. Vereinigte Fachverlage, Mainz

35. Schleich TJ (2013) Temperatur- und Verlustleistungsverhalten von Wälzlagern in Getrieben. Dissertation, TU München, München

36. Schlenk L (1995) FVA 166 I: Größeneinfluß Fressen - Freßtragfähigkeit von einsatzgehärteten und zahnflankengeschliffenen Großzahnrädern. Abschlussbericht. FVA, Frankfurt a.M.

37. SKF New SKF engineering software for the evaluation of bearing arrangements - SKF SimPro Quick is an easy-to-use bearing analysis tool with advanced features. https://evolution.skf.com/ us/new-skf-engineering-software-for-the-evaluation-of-bearingarrangements/. Accessed 5 July 2021

38. SKF The SKF model for calculating the frictional moment. https:// www.skf.com/binary/21-299767/The0SKF0model0for0calcula ting0the0frictional0movement_tcm_12-299767.pdf. Accessed 24 August 2021

39. SKF Gruppe (2004) Wälzlager. SKF-Gruppe, Schweinfurt (PUB BU/P1 $6000 \mathrm{EN})$

40. Stangl M (2007) Methodik zur kinematischen und kinetischen Berechung mehrwelliger Planeten-Koppelgetriebe. Dissertation, TU München, Garching

41. Stangl M, Kurth F, Geiger J, Sedlmair M, Paschold C (2021) FVAEDV Programm WTplus - Benutzeranleitung v1.5. Forschungsvereinigung Antriebstechnik (FVA) e. V., Frankfurt a.M.

42. Stribeck R (1903) Die wesentlichen Eigenschaften der Gleit- und Rollenlager. Springer, Berlin, Heidelberg, New York

43. Sucker J (2013) Entwicklung eines Tragfähigkeitsberechnungsverfahrens für Schraubradgetriebe mit einer Schnecke aus Stahl und einem Rad aus Kunststoff. Dissertation, Ruhr Universität Bochum, Bochum

44. Walter P (1982) FVA 44 I - Anwendungsgrenzen für die Tauchschmierung von Zahnradgetrieben - Plansch- und Quetschverluste bei Tauchschmierung. Abschlussbericht. Forschungsvereinigung Antriebstechnik (FVA) e. V., Frankfurt a.M.

45. Wang D, Poll G (2012) FVV-Nr. 609812, Low Friction Powertrain - G2.1 Wirkungsgradoptimiertes Getriebe. Abschlussbericht. Forschungsvereinigung Verbrennungskraftmaschinen (FVV) e. V., Frankfurt a.M.

46. Wimmer AJ (2006) Lastverluste von Stirnradverzahnungen - Konstruktive Einflüsse, Wirkungsgradmaximierung, Tribologie. Dissertation, TU München, Garching

47. Xiao H, Tang D, Deng Z, Li C, Kong F, Jiang S (2017) Thermal analysis and experimental verification of the transmission in a lunar drilling system. Appl Therm Eng 113:765-773 